\title{
GEOLOGY OF THE KOMANDORSKY DEEP BASIN
}

\author{
Nikita A. Bogdanov \\ Institute of the Lithosphere, USSR Academy of Sciences, \\ Moscow, USSR
}

\begin{abstract}
This paper deals with the distribution of various geological structures of the Komandorsky deep basin of the Bering Sea. The data allow the supposition that it was formed as a result of spreading during late Cretaceous and Tertiary periods. The Shirshov Ridge framing the Komandorsky deep basin in the west is heterogenous. It is a Late Cretaceous island arc in the west and a Tertiary zone of tectonic convergence in the east. Processes of the Quaternary tectonic activity within the Komandorsky Basin are emphasized.
\end{abstract}

\section{Introduction}

Evolution of deep sea basins of marginal and inner seas is the focus of attention of many specialists preoccupied with elaboration of the theory of tectonics of the lithospheric plates. Investigations in many regions (the East China and South China Seas, the Lau Basin, etc.) show that the spreading was active within their limits in the Cenozoic period. In this connection the Bering Sea draws special attention, where a portion of the Kula plate separated from the Pacific by the Aleutian Island arc, is supposed to be preserved. Evolution processes in the western part of this plate are the focus of the present paper.

\section{Komandorsky Basin}

The Komandorsky Basin is located in the western part of the Bering Sea. It is separated from the Aleutian Basin by the system of the Shirshov-Bowers undersea ridges and from the Asian continent by a relatively narrow shelf. It is well known that while the trends of geological features and magnetic anomalies on the shelf of the Aleutian Basin, in Alaska, as well as in Koryakia are parallel to the northern boundary and cross the magnetic anomalies of the deep basin at nearly a right angle, the aero-magnetic anomalies of the deep Komandorsky Basin extend northwards into the shelf and further they correspond to this or that mountaneous structures of the Olyutor zone. In the far west, lines of nappes are parallel to the zone. The nappes can be traced along the front of ophiolite sheets and other deep-water formations. The envelope of tectonic sheets stretches from the Govena Peninsula southwards across the Karaginsky Island reaching the Kamchatka Cape.

Acoustic basement of the Komandorsky Basin is overlain by a $1.5-2.0 \mathrm{~km}$ thick 
sedimentary cover. According to the continuous seismic profiling data, the rocks of the sedimentary cover are represented by the upper well-stratified and the lower acoustically transparent horizons with seismic velocities of $1.83,2.60,3.10$, and $5.75 \mathrm{~km} / \mathrm{s}$ (RABINOWITZ and COOPER, 1977). Sometimes the tops of the buried mountains rise above the sedimentary cover; under the cover the mountains form a system of linear and slightly curved ridges. Their amplitude of rise is $0.5-1.5 \mathrm{~km}$. Approaching the Shirshov Ridge, the basement of the Basin in general rises.

The character of the magnetic anomalies may be related to that of the magmatic rocks of the basement. The depth of $M$ discontinuity under the Basin is $9-10 \mathrm{~km}$, i.e., the thickness of the crust here is comparable with the thickness of normal oceanic crust.

The heat flow in the Komandorsky Basin is approximately 2.5 times that in the Aleutian Basin. Its values range from 110.5 to $210.6 \mathrm{~mW} / \mathrm{m}^{2}$. The minimal ones are localized in the north-west, progressively increasing to the south-west. According to SMIRNOv et al. (1982) such a heat flow can be explained by the high position of $1,100^{\circ} \mathrm{C}$ isotherm under the Komandorsky Basin, which in turn, can be explained

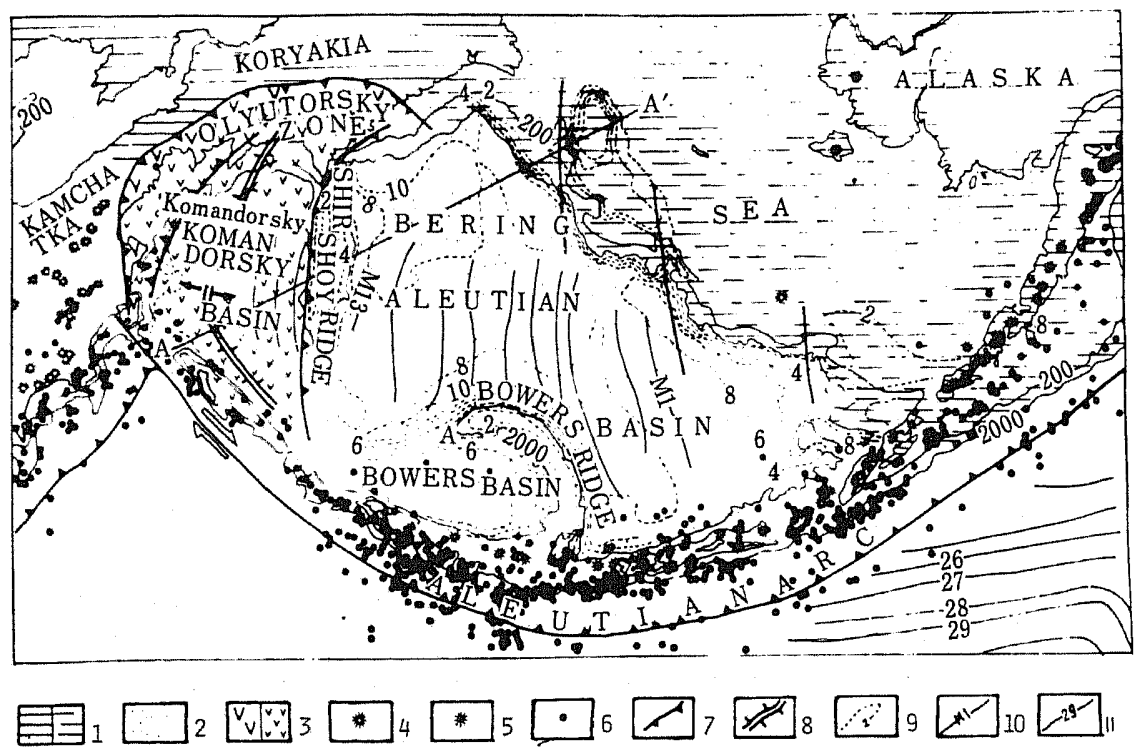

Fig. 1. Structural-tectonic scheme of the Bering Sea region (according to Bogdanov and Neprochnov, 1984). 1, Areas of the Mesozoic fold zone and pre-Albian accretion prism; 2, pre-Albian oceanic plate; 3, pre-Middle Miocene oceanic plate; 4 , active volcanoes; 5 , extinct volcanoes; 6 , epicenters of earthquakes; 7, subduction zones; 8, axis of spreading; 9, thickness of sediments on the Aleutian plate and on the edge of the shelf (isolines in $2 \mathrm{~km}$ ); 10, magnetic anomalies in the Bering Sea (according to CoOPER et al., 1976); 11, magnetic anomalies on the Pacific plate. 


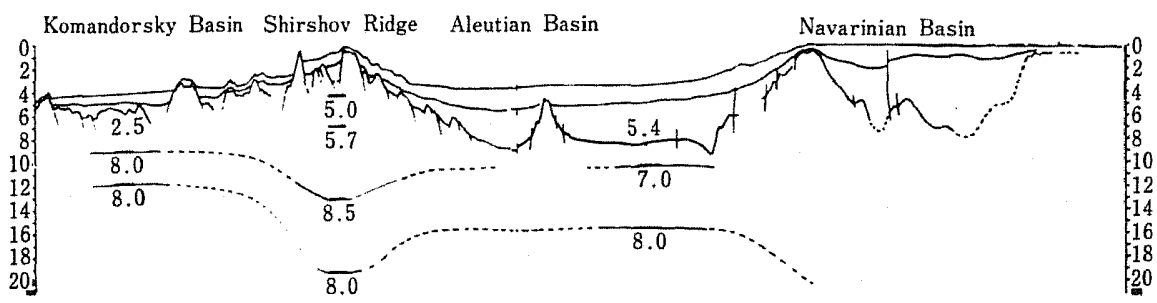

Fig. 2. Combined seismic section across the Bering Sea. See Fig. 1 for the location of the section.

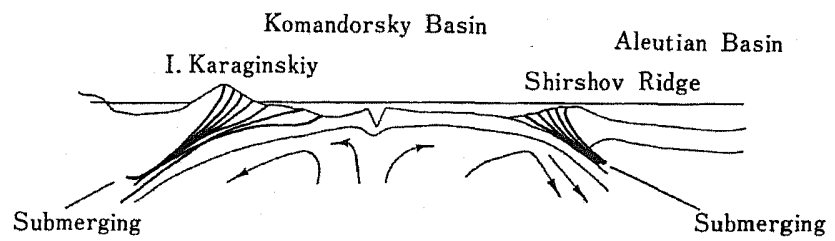

Fig. 3. Tectonic section across the Komandorsky deep basin.

by a young spreading origin of the acoustic basement. The Basin is characterized by seismic anisotropy in the mantle (SHOR and FORNARI, 1976), which is consistent with E-W spreading.

Steep scarps framing the Basin in the west (along the continental slope) and in the east (near the Shirshov Ridge), and also complicated tectonic dislocations along them, show the presence of reverse faults inclining under the Shirshov Ridge and the continental slope.

Section of the sedimentary cover of the basin was revealed at DSDP Site 191 (CREAGER et al., 1973) in its eastern part, which by its morphostructural properties is more similar to the slope of the Shirshov Ridge than to the central basin. At this point the thickness of the sedimentary cover reaches $900 \mathrm{~m}$. The upper part of the section is made of interbedded distal turbidites and diatomaceous silts and clays as well as of fine-grained sandstones and volcanic ashes of the upper MioceneHolocene age. Dense argillites and aleurolites of the Middle Miocene age prevail in the lower part. They rest on the diffuse surface of tholeiitic basalts, the age of which, defined radiometrically, is $29.6 \mathrm{Ma}$ (Middle Oligocene) (Bogdanov and Neprochnov, 1984). Taking into account the morphology of the bed and the available geophysical data one can suppose that the basalts of south-western and western parts of the Komandorsky Basin are younger. The Shirshov Ridge is the key structure for the understanding of the history of deformation in the western part of the Bering Sea.

\section{Shirshov Ridge}

The Shirshov Ridge separates, as mentioned above, the Aleutian and 
Komandorsky Basins. It begins at the Aleutian arc and forms a continuous system of mountains $900 \mathrm{~km}$ long and $50-80 \mathrm{~km}$ wide. It is traced through the Olyutor Peninsula up to the thrust between the Olyutor and North-Koryakia zones. The ridge rises $1,000-2,200 \mathrm{~m}$ above the bed of the adjacent basins, and generally has asymmetrical structure-its eastern slope is less steep than the western one. The ridge consists of parallel chains, the height of which increases in the axial zone. The whole ridge, excluding steep scarps of the western slopes, where their amplitude reaches $700-800 \mathrm{~m}$, is covered by sediments, which in the mountain valley attain a thickness of $1-3 \mathrm{~km}$. The structure of the sedimentary cover is complicated by deformations and rupture dislocations. The formation of these dislocations evidently is caused by intensive current movements, characteristic for the whole western part of the Bering Sea.

The geological nature of the Shirshov Ridge was widely discussed in literature. DEMENTJEV (1978) put forward an idea of the rift origin of the Ridge, considering that it coincided with a Late Mesozoic spreading center. There are also some geotectonic patterns suggesting that the Shirshov Ridge represents the northern extremity of the Emperor Seamounts shifting along the Komandorsky slip, i.e., its origin is connected with the passing of the oceanic plate over the hot spot. And finally, SCHOLL (1975) considered the Shirshov Ridge to be a Cretaceous island arc, forming the joint system with the Bowers Ridge. Until recent years there has been almost a complete lack of data on the geological structure of the Ridge. That is why all the above-mentioned hypotheses were based on indirect interpretations of different geophysical data only.

Deep seismic sounding carried out in the Shirshov Ridge for the first time during the 29th leg of the "Dmitry Mendeleev" revealed the crustal layer velocities of $1.8,3.2,4.0-4.5,5.0$, and $6.8 \mathrm{~km} / \mathrm{s}$. The total thickness of the crust is $18-20 \mathrm{~km}$, i.e., two times thicker than that of the crust to the west. Geomagnetic observations of the Komandorsky Basin carried out during the 29th leg showed that the western part of the Ridge is characterized by linear anomalies, while the eastern one at least up to the depth of $4-5 \mathrm{~km}$, is formed by nonmagnetic rocks (NEPROCHNOV et al., 1985).

These observations are supported by dredged samples. During the 29th leg, dredging was carried out over the western slope and axial part of the ridge. On the western slope outcrops of intensively tectonized and mylonitized gabbroids, dolerites, and banded amphibolites were discovered. The age of basalts from the latest determinations carried out by means of $\mathrm{K} / \mathrm{Ar}$ method in the laboratories of the Institute of Ore Deposits, Petrography, Mineralogy and Geochemistry of the USSR Academy of Sciences, is $36 \pm 3 \mathrm{Ma}$ (Middle Oligocene). Judging from the character of sediments-siliceous argillites, grits and sandstones of the Miocene age-tectonic deformations in the eastern part of the Ridge took place earlier. It is evident that olivine and olivine-pyroxene-plagioclase basalts are the youngest magmatic rocks here. According to SCHOLL et al. (1975) their age is the Middle Miocene (16.8 Ma). Dredging of the central part of the Shirshov Ridge demonstrated a prevailing 
distribution of basalts and siliceous rocks. The latter are represented by strongly lithified formations of grey, grey-greenish, and violet colour. They differ in purity of their composition. These are fine-grained quartz-chalcedony and crystoballiticchalcedony rocks. Complete skeletons of radiolaria compose no more than $25 \%$ of rocks and about the same amount is represented by organogeneous detrites. The bulk is made up by fine-grained siliceous and clay-siliceous matter.

These rocks were accumulated under calm conditions, close to those of abyssal plains. Good preservation of fine skeletons of diatoms and fragile delicate radiolarian forms bear witness to that. Extracted microfossils dated the rocks as the late Cretaceous (Campanian-Maastrichtian)-Early Paleocene. The composition of the Upper Cretaceous cherts of the Shirshov Ridge proves that they were accumulated in the calmest and deepest parts of the basin at a considerable distance from the source of clastic and volcanic material. The upper layers of the central and eastern parts of the Shirshov Ridge are traced towards the Aleutian Basin and, probably, form its upper horizon of acoustic basement.

Thus the Shirshov Ridge presents a zone of conjunction, where two blocks of oceanic crust-the Aleutian plate formed in pre-Tertiary time and the Komandorsky one which continued to form to the Middle Miocene-converged and shallow subduction took place.

The structure of the Ridge discussed above is well expressed in its northern extension within the Olyutor zone.

\section{Discussion and Conclusion}

So far we have dealt with the main features of geological and geophysical structure of the deep basins of the Bering Sea and its margin. In considering the tectonic history of the Bering Sea region we have to take the following factors into account.

The acoustic basement of the Aleutian Basin is formed by the oceanic plate of the same name, the formation of which was completed in the Albian (about $110 \mathrm{Ma}$ ago). According to geological data the mid-oceanic ridge during this epoch stretched parallel to the recent continental margin and the upper Cretaceous terrigenous wedge. In this connection, there appears a question of interpretation of meridional magnetic anomalies, established by COOPER et al. (1976) in the central part of the Aleutian plate. They were correlated with anomalies M1-M13 according to the Larson scale (117-132 Ma). In general the magnetic anomalies are parallel to the uprising of the acoustic basement and the buried Bartlett and Sounder Ridges, as well as to the Shirshov Ridge. Therefore we can assume that the Aleutian part of the Kula plate, before moving northward, rotated at $90^{\circ}$.

According to the seismoacoustic data the sedimentary cover of the basin is subdivided into three horizons with different ages: the lower one (velocities 3.4 $3.9 \mathrm{~km} / \mathrm{s}$ ) - the late Cretaceous-Eocene; the middle one (velocity $2.7 \mathrm{~km} / \mathrm{s}$ ) - the Oligocene-Early Miocene; the upper one (velocity $1.6 \mathrm{~km} / \mathrm{s}$ )-the Miocene- 
Quaternary (BEN-AvRAHAM and COOPER, 1981). The Aleutian plate split from the Pacific one in the latest Cretaceous along a large transform zone, which was a part of the system of the East-Pacific transform lineament (Mendocino, Murrey, Clipperton and others). In Tertiary time, as a result of initiation of subduction the transform fault zone transformed into a system of the Aleutian arc-trench, thus completing the isolation of the Bering Sea from the ocean (HILDE et al., 1977).

As discussed in this paper, the Komandorsky Basin differs considerably from the Aleutian one and the adjacent oceanic regions in its geological and geophysical patterns. The basin basement has deeply dissected young relief. The basin is characterized by a high heat flow and anisotropy of mantle rocks. All these peculiarities and close structural relations of the Basin and structures of the Olyutor zone in Koryakia suggest a mechanism of the Basin formation quite different from that of the Aleutian Basin. If the Aleutian Basin was generated within the fragment of the lower Cretaceous Kula plate then the Komandorsky Basin was formed as a result of local spreading in the west side of the Kula plate, which began at the end of the latest Cretaceous time and was in progress till the Late Miocene time.

The Basin is asymmetric - its younger part is narrower and located at the foot of the Kamchatka's continental slope. The axis of spreading is shifted to the west and oriented meridionally and parallel to the late Cretaceous structural elements. Therefore it is logical to suggest that deformation started along the largest structure of such a type. The spreading was compensated by the subduction of oceanic crust under the continental one (in the west) with the formation at the first stage of Andean-type island arc volcanism which was replaced in Oligocene and Miocene time by the obduction and formation of the Vyvenka-Karaginsky accretionary prism. Eastward in the Shirshov Ridge area the subduction of a young (late Cretaceous and Early Tertiary) oceanic crust of the Komandorsky Basin under the Middle Cretaceous (Albian) oceanic crust of the Aleutian plate occurred. The subduction was accompanied by the formation of numerous horizontal displacements, a zone of nappe structures and oceanic convergence. In the late Tertiary time the central part of the Basin was filled by calc-alkaline volcanic rocks and sedimentary clastic series. Active spreading in the Komandorsky Basin probably caused the cessation of subduction in the western part of the Aleutian trench and transformation of the Benioff zone in this region into right-lateral strike slip fault. Since Late Miocene time island arc volcanism and seismic activity have not been characteristic of the Komandor Islands. At the same time earthquakes occurred along the continental margin within the Govena Peninsula, the Karaginsky Island, and the Kamchatka Cape Peninsula. The Komandorsky Basin, in the mechanism of its formation, is similar to the Parece-Vela Basin in the Philippine Sea (KARIG, 1972).

The undersea Shirshov Ridge and its continental extension, the Olyutor Ridge, appear to be the remnant volcanic arc which was formed above the subduction zone where two oceanic plates were merging. The Shirshov Ridge is composed of oceanic tholeiites of the Albian age in the east and of the Middle Oligocene age in the west. 
The Late Cretaceous volcanism of the Ridge suggests that the subduction of the Komandorsky plate under the Aleutian one occurred along the zone of transform rift. Probably, the Shirshov Ridge in the Early Cretaceous time was the northern extension of the Emperor Ridge (BEN-A VRAHAM and UYEDA, 1983). As a result of spreading in the Komandorsky Basin the Ridge moved eastwards along the Komandorsky-Aleutian fault.

Contrasting tectonic movements in the Bering Sea region have been best manifested since the Middle Oligocene time. At this time large superimposed basins - the Khatyrka, Navarin, Anadyr and others - were formed and started to be filled by terrigenous sediments derived from the continents. These basins may serve as large reservoirs for oil and gas.

\section{REFERENCES}

Ben-Avraham, Z. and A. K. Cooper, Early evolution of the Bering Sea by collision of oceanic rises and North Pacific subduction zone, Geol. Soc. Am. Bull., 92, 485-495, 1981.

BEN-AVRAhAM, Z. and S. UYEDA, Entrapment origin of marginal seas, in Geodynamics of the Western Pacific Region, ed. T. W. C. Hilde and S. Uyeda, Geodynamics Series V. 11, pp. 91-104, Am. Geophys. Union, Geol. Soc. Am., Washington, D. C., 1983.

Bogdanov, N. A. and Yu. P. Neprochnov, Geology of the Bering Sea deep basins. in Origin and History of Marginal and Inland Seas, Proceedings of the 27th IGC, Vol. 23, pp. 1-17, VNU Science Press, Utrecht, 1984.

Cooper, A. K., M. S. Marlow, and D. W. Scholl, Mesozoic magnetic lineation in the Bering Sea marginal basin, J. Geophys. Res., 81, 1916-1934, 1976.

Creager, J., D. W. Scholl, R. E. Boyce et al., Initial Reports of the Deep Sea Drilling Project, Vol. 19, U.S. Government Printing Office, Washington, 913 pp., 1973.

Dementuev, G. B., Priroda i vozrast glubokovodnoy chasti Beringova morya po dannym paleomagnitnykh issledovaniy, Materialy v nauchnoy konferenzii aspirantov i molodyh uchenyh geol, fakulteta MGU, VINITI, pp. 130-139, 1978 (in Russian).

Hilde, T. W. C., S. UyedA, and L. KroenKe, Evolution of the western Pacific and its margin, in Present State of Plate Tectonics, ed. J. Bonnin and R. S. Dietz, Tectonophysics, 38 (1-2), 145-165, 1977.

Karig, D. E., Remnant arcs, Geol. Soc. Am. Bull., 83, 1057-1068, 1972.

Neprochnov, Yu. P., V. V. Sedov, L. P. Merkin, V. P. Zinkevich, O. V. Levchenko, B. V. BARANOv, and G. B. RudnIK, Tektonicheskaya structura khrebta Shirshova (Beringovo more), Geotectonica, 3, 21-38, 1985 (in Russian).

RABINOWITZ, P. and A. K. COOPER, Structure and sediment distribution in the western Bering Sea, Mar. Geol., 24, 309-320, 1977.

Scholl, D. W., E. C. Buffington, and M. S. Marlow, Plate tectonics and structural evolution of the Aleutian-Bering Sea region, Geol. Soc. Am., Spec. Pap., 151, 1-31, 1975.

SHOR, A. A. and D. J. ForNARI, Seismic refraction measurements in the Kamchatka Basin, Western Bering Sea, J. Geophys., 3, 5260-5266, 1976.

Smirnov, Ya. B., V. M. Sugrobov, and Yu. I. Galushkin, Teplovoi potok v zone sochleneniya Aleutskoy i Kurilo-Kamchatskoy ostrovoduzhnyh sistem, Vulkanologia $i$ seismologia, 6, 96-115, 1982 (in Russian). 